\title{
Binding of High Molecular Weight Kininogen to Human Endothelial Cells Is Mediated via a Site within Domains 2 and 3 of the Urokinase Receptor
}

\author{
Robert W. Colman, ${ }^{\star \ddagger}$ Robin A. Pixley, ${ }^{\star}$ Syeda Najamunnisa, ${ }^{\star}$ Wuyi Yan, ${ }^{\star}$ Jieyi Wang, ${ }^{\S}$ Andrew Mazar, and Keith R. McCrae ${ }^{\star \ddagger}$ \\ *The Sol Sherry Thrombosis Research Center and ${ }^{\ddagger}$ Department of Medicine, Temple University School of Medicine, Philadelphia, \\ Pennsylvania 19140; ${ }^{\S}$ Abbott Laboratories, Pharmaceutical Products Division, Abbott Park, Illinois 60064; and $\|_{\text {Angstrom }}$ \\ Pharmaceuticals, San Diego, California 92121
}

\begin{abstract}
The urokinase receptor (UPAR) binds urokinase-type plasminogen activator (u-PA) through specific interactions with UPAR domain 1 , and vitronectin through interactions with a site within UPAR domains 2 and 3. These interactions promote the expression of cell surface plasminogen activator activity and cellular adhesion to vitronectin, respectively. High molecular weight kininogen (HK) also stimulates the expression of cell surface plasminogen activator activity through its ability to serve as an acquired receptor for prekallikrein, which, after its activation, may directly activate prourokinase. Here, we report that binding of the cleaved form of $\mathrm{HK}(\mathrm{HKa})$ to human umbilical vein endothelial cells (HUVEC) is mediated through zinc-dependent interactions with UPAR. These occur through a site within UPAR domains 2 and 3 , since the binding of ${ }^{125} \mathrm{I}-\mathrm{HKa}$ to HUVEC is inhibited by vitronectin, anti-uPAR domain 2 and 3 antibodies and soluble, recombinant UPAR (suPAR), but not by antibody $7 \mathrm{E} 3$, which recognizes the $\beta$ chain of the endothelial cell vitronectin receptor (integrin $\alpha_{v} \beta_{3}$ ), or fibrinogen, another $\alpha_{v} \beta_{3}$ ligand. We also demonstrate the formation of a zinc-dependent complex between suPAR and HKa. Interactions of HKa with endothelial cell UPAR may underlie its ability to promote kallikrein-dependent cell surface plasmin generation, and also explain, in part, its antiadhesive properties. (J. Clin. Invest. 1997. 100:1481-1487.) Key words: plasminogen - vitronectin - prourokinase • prekallikrein • integrin $\alpha_{\mathrm{v}} \beta_{3}$
\end{abstract}

\section{Introduction}

In the presence of zinc ions, high molecular weight kininogen $(\mathrm{HK})^{1}$ binds to endothelial cells specifically, saturably, and reversibly, with a $K_{\mathrm{d}}$ of $28-35 \mathrm{nM}$ and $\mathrm{B}_{\max }$ of $0.9-3.2 \times 10^{6}$ sites per endothelial cell (1-4). Cell-associated HK, or its cleaved, two-chain form, HKa, can serve as an acquired endothelial cell

R.W. Colman and R.A. Pixley contributed equally to this project.

Address correspondence to Keith R. McCrae, M.D., Sol Sherry Thrombosis Research Center, OMS 300, Temple University School of Medicine, 3400 North Broad Street, Philadelphia, PA 19140. Phone: 215-707-2523; FAX: 215-707-2783; E-mail: kmccra00@nimbus. ocis.temple.edu

Received for publication 26 February 1997 and accepted in revised form 1 July 1997.

J. Clin. Invest.

(C) The American Society for Clinical Investigation, Inc. 0021-9738/97/09/1481/07 \$2.00

Volume 100, Number 6, September 1997, 1481-1487

http://www.jci.org receptor for plasma prekallikrein or Factor XI (5-7), the latter of which is converted to Factor XIa by Factor XIIa, allowing the assembly and expression of an intrinsic Factor IX activator complex on endothelial cells (5). Prekallikrein bound to HK is converted to kallikrein on the endothelial surface (8), subsequently liberating bradykinin from $\mathrm{HK}$ and resulting in the generation of $\mathrm{HKa}(9)$. Bradykinin binds to endothelial B2 receptors (10), and may stimulate endothelial cell hyperpolarization (11), as well as the synthesis and release of prostacyclin (12), superoxide anion (13), tissue plasminogen activator (14), and nitric oxide (15). In comparison to $\mathrm{HK}$, relatively little attention has been devoted to characterization of the binding of $\mathrm{HKa}$ to cells, though data from one report suggested that only $\sim 25 \%$ as much $\mathrm{HKa}$ as $\mathrm{HK}$ specifically bound to endothelial cells (16). Whether these differences result from different affinities of these species for a single receptor, or binding to different receptors, has not been determined.

Structural determinants on HK which mediate its binding to endothelial cells have been described. HK is composed of six defined domains, denoted D1-D6 (17). The release of bradykinin (D4) results in the generation of $\mathrm{HKa}$, which consists of an $\mathrm{NH}_{2}$-terminal 65-kD heavy chain composed of three cystatin-like domains (D1, D2, and D3), and a COOH-terminal 56-kD light chain containing a histidine-glycine-lysine-rich domain (D5) and a prekallikrein and Factor XI binding domain (D6). Endothelial cell binding sites reside on both the heavy and light chains (18). One site on D3 (19), near the carboxy terminus of the heavy chain, has been localized to a 13amino acid sequence containing a disulfide loop (20), while a second high-affinity binding site, located on D5 of the light chain (21), is essentially identical to one of the two sites which mediate the binding of HK to anionic artificial surfaces (22, 23). Additionally, a low-affinity site on D4 overlaps with the bradykinin sequence (16). The absence of this region in $\mathrm{HKa}$ has been suggested as a potential explanation for the differences in binding of HK and HKa to endothelial cells (16).

Through its ability to bind urokinase and focus the expression of cell surface plasminogen activator activity to discrete sites on the cell surface, the urokinase-type plasminogen activator receptor ( $\mathrm{UPAR}$ ) facilitates the generation of cell surface plasminogen activator activity $(24,25)$. This receptor plays a central role in diverse processes involving cellular migration, including angiogenesis $(26,27)$, formation of the placental vasculature after embryo implantation (28), tumor metastasis (29), and the migration of leukocytes into inflammatory foci.

1. Abbreviations used in this paper: $\mathrm{HK}$, high molecular weight kininogen; HKa, cleaved, bradykinin-free HK; HUVEC, human umbilical vein endothelial cells; GPI, glycosylphosphatidylinositol; PA, plasminogen activator; PI-PLC, phosphatidylinositol-specific phospholipase $\mathrm{C}$; suPAR, a soluble recombinant form of UPAR; UPAR, urokinasetype plasminogen activator receptor. 
The uPAR is a glycosylphosphatidylinositol (GPI)-linked protein consisting of three domains $(30,31)$. The $\mathrm{NH}_{2}$-terminal domain, D1, at least when contained within the intact receptor, mediates high-affinity binding of pro- or two-chain urokinase (32-34), while domains 2 and 3 contain a binding site for, and mediate cellular adhesion to, vitronectin $(35,36)$.

In this report we demonstrate that the urokinase receptor mediates the binding of $\mathrm{HKa}$ to cultured human umbilical vein endothelial cells (HUVEC). HKa binds to a site within domains 2 and 3 of uPAR which is identical to or nearby that which mediates the binding of vitronectin. We also demonstrate that endothelial cell $\alpha_{\mathrm{v}} \beta_{3}$ is not a receptor for HKa. These observations provide a potential explanation for the different binding properties of $\mathrm{HKa}$ and $\mathrm{HK}$ to endothelial cells (16), as well as the ability of HK to inhibit endothelial cell adhesion to vitronectin (37) and promote the expression of plasminogen activator activity on the endothelial cell surface (8).

\section{Methods}

Human fibrinogen, HK, and HKa were purchased from Enzyme Research Laboratories (South Bend, IN). Fibrinogen was homogeneous as judged by SDS-PAGE, and was plasminogen-free and $>95 \%$ clottable. HKa and prourokinase were radiolabeled with ${ }^{125} \mathrm{I}-\mathrm{Na}$ (ICN Pharmaceuticals, Irvine, CA) using Iodogen or Iodobeads, respectively (Pierce Chemical Co., Rockford, IL) (38). The specific radioactivity of $\mathrm{HKa}$, which retained $>95 \%$ of its procoagulant activity, varied from 0.5 to $1.5 \mathrm{mCi} / \mu \mathrm{g}$. Vitronectin was obtained from GIBCO BRL (Gaithersburg, MD). A monoclonal antibody to the integrin $\beta_{3}$ chain, which inhibits vitronectin binding to $\alpha_{v} \beta_{3}$, the primary endothelial cell vitronectin receptor, as well as the binding of fibrinogen to its receptor on platelets $\left(\alpha_{\mathrm{II}} \beta_{3}\right)$, was kindly supplied as purified IgG by Dr. Barry Coller (Mt. Sinai Medical School, New York).

Expression of soluble recombinant $u P A R$ (suPAR). Human suPAR cDNA (encoding aa 1-281 with the signal peptide) was prepared from U937 cells by RT-PCR and cloned into pDEMp, an expression vector for murine hybridoma cells. This vector was transfected into the murine hybridoma cell line Sp2/0 and the clones were selected by growing the cells in DMEM containing $10 \%$ FBS and increasing concentrations of methotrexate $(150 \mathrm{nM}$ to $1 \mu \mathrm{M})$. The concentration of suPAR secreted into the medium was determined by ELISA (American Diagnostica, Greenwich, CT). Large scale expression was accomplished by growing the stably transfected cells in spinner flasks containing serum-free medium (Gibco Laboratories, Grand Island, NY). Media from large scale cultures (100 liters, 20-40 mg suPAR/liter) were obtained on day 8 after seeding, stabilized with protease inhibitors (5 mM EDTA, $100 \mu \mathrm{M}$ PMSF, $5 \mu \mathrm{M}$ aprotinin, $5 \mu \mathrm{M}$ leupeptin), concentrated, and stored at $-70^{\circ} \mathrm{C}$ until purified.

To isolate suPAR, pro-uPA $(500 \mathrm{mg})$ was immobilized on CNBragarose, and equilibrated with PBS containing $10 \mu \mathrm{M}$ EDTA. Concentrated medium $(200 \mathrm{ml})$ was applied to the column, which was then sequentially washed with PBS, PBS containing $1 \mathrm{M} \mathrm{KCl}$, and PBS alone until the $A_{280}$ of the flow-through returned to 0. suPAR was then eluted using $0.2 \mathrm{M}$ glycine, $\mathrm{pH}$ 3.0. The eluted protein was gel-filtered on Sephacryl S-300 (Pharmacia, Piscataway, NJ), and migrated as a single band between 35 and $45 \mathrm{kD}$ on SDS-PAGE.

Production of UPAR domain 2 and 3-specific polyclonal antibodies. suPAR was cleaved using chymotrypsin (5,000:1 molar ratio) for $24 \mathrm{~h}$ at $4^{\circ} \mathrm{C}$, as previously described (32). The uPAR domain 1 was separated from domains 2 and 3 (aa 88-281) using Sephadex-G50 equilibrated with PBS. Further purification of each domain was achieved using $\mathrm{C} 8$ reverse-phase chromatography, with a linear gradient of $0-70 \%$ acetonitrile $/ 0.1 \%$ TFA over 60 min. Purified uPAR domains 1,2 , and 3 were then used to generate domain-specific polyclonal antibodies in rabbits. Immunoglobulins were isolated from the serum of immunized rabbits by ammonium sulfate precipitation, followed by affinity chromatography on a suPAR-Sepharose column.

Isolation and culture of endothelial cells. HUVEC were isolated as described $(39,40)$, and cultured in medium 199 containing $10 \%$ FBS, $100 \mu \mathrm{g} / \mathrm{ml}$ endothelial cell growth factor [purified as described by Maciag (41)], 2 mM glutamine, and penicillin-streptomycin (Mediatech, Herndon, VA). All studies were performed using HUVEC of passage 3 or less. Before binding studies, cells were released from culture dishes using trypsin-EDTA (Mediatech), then replated and cultured until confluent in fibronectin-coated 96-well Immulon II plates (Dynatech, McLean, VA), which caused less nonspecific binding of ${ }^{125} \mathrm{I}-\mathrm{HKa}$ than standard 96-well polystyrene tissue culture plates. At confluence, each well of the 96-well plate contained a mean of $35,000 \pm 5,000$ cells per well. In selected experiments, HUVEC were preincubated at $37^{\circ} \mathrm{C}$ with $1 \mathrm{U} / \mathrm{ml}$ phosphatidylinositol-specific phospholipase C (PI-PLC; Sigma, St. Louis, MO) which cleaves the glycophosphatidylinositol linkage of uPAR to the cell membrane, for $2 \mathrm{~h}$ before binding experiments. The efficacy of UPAR release after PI-PLC treatment was confirmed by measuring the specific binding of ${ }^{125} \mathrm{I}$-prourokinase to control and PI-PLC-treated cells.

Binding of ${ }^{125} \mathrm{I}-\mathrm{HKa}$ and ${ }^{125} \mathrm{I}$-prourokinase to endothelial cells. After achieving confluence, HUVEC were chilled to $4^{\circ} \mathrm{C}$. Conditioned medium was then removed, and the cells were preincubated for $20 \mathrm{~min}$ in cold Hepes buffer $(10 \mathrm{mM}$ Hepes, $137 \mathrm{mM} \mathrm{NaCl}, 4 \mathrm{mM}$ $\mathrm{KCl}, 11 \mathrm{mM}$ glucose, $0.5 \mathrm{mg} / \mathrm{ml}$ fatty acid-free BSA, and $1 \mathrm{mM} \mathrm{CaCl}_{2}$, $\mathrm{pH}$ 7.35) containing (for total binding) or lacking (for nonspecific binding) $50 \mu \mathrm{M} \mathrm{ZnCl}_{2}$. The binding of ${ }^{125} \mathrm{I}-\mathrm{HKa}$, diluted in $100 \mu \mathrm{l}$ of Hepes buffer (in the absence or presence of $50 \mu \mathrm{M} \mathrm{ZnCl}_{2}$ ), to individual wells of HUVEC was then determined. After a 60-min incubation period, the concentration of "free" ligand in each well was determined by measuring the radioactivity in a $10-\mu l$ aliquot of the binding solution, and the cell-associated radioactivity by solubilizing the cells in $150 \mu \mathrm{l}$ of $1 \%$ SDS after washing twice with Hepes buffer. Specific binding was defined as the difference between total and nonspecific (no added $\mathrm{ZnCl}_{2}$ ) binding. Data obtained in preliminary studies agreed with those of previous reports (1-4), in which it was observed that the binding of ${ }^{125} \mathrm{I}-\mathrm{HKa}$ in the absence of $\mathrm{ZnCl}_{2}$ and in the presence of a 50-fold molar excess of HKa, was equivalent, and hence representative of nonspecific binding. In selected studies, the effects of specific antibodies or other putative inhibitors of ${ }^{125} \mathrm{I}-\mathrm{HKa}$ binding to cells were assessed by preincubating cells for $60 \mathrm{~min}$ with the test reagent before addition of ${ }^{125} \mathrm{I}-\mathrm{HK}$. Specific inhibitors which were tested included fibrinogen $(0-3,500 \mathrm{nM})$, vitronectin $(0-180 \mathrm{nM})$, $\mathrm{mAb} 7 \mathrm{E} 3(0-2,000 \mathrm{nM})$, prourokinase $(0-500 \mathrm{nM})$, and soluble urokinase receptor $(0-600 \mathrm{nM})$. Total or specific binding for each experiment is expressed as picomoles of HKa bound, normalized per $10^{6}$ cells. For studies in which the effects of competitors on the binding of a fixed concentration of ${ }^{125} \mathrm{I}-\mathrm{HKa}$ were assessed, the data are expressed as percentage of the original ligand bound in the absence of competitor.

The binding of ${ }^{125} \mathrm{I}$-prourokinase to endothelial cells was determined in a similar manner, though these studies were performed in PBS containing $1 \%$ BSA, with nonspecific binding determined in the presence of a 100 -fold molar excess of unlabeled prourokinase, as previously described (42).

Demonstration of a ${ }^{125} \mathrm{I}-\mathrm{HK} a-\mathrm{SUPAR}$ complex by gel filtration. G-200 Superfine Sepharose (Pharmacia) was packed in a $0.9 \times 60 \mathrm{~cm}$ polystyrene column. The gel was equilibrated in a buffer consisting of $0.01 \mathrm{M}$ Hepes, $0.137 \mathrm{M} \mathrm{NaCl}, 0.004 \mathrm{M} \mathrm{KCl}, 0.011 \mathrm{M}$ glucose, $0.001 \mathrm{M}$ $\mathrm{CaCl}_{2}$, and $50 \mu \mathrm{M} \mathrm{ZnCl}$, $\mathrm{pH} 7.35$ (equilibration buffer). Mixtures of ${ }^{125}$ I-labeled HKa or HK (65-75 nM) and unlabeled suPAR or suPAR domains 2 and $3(1 \mu \mathrm{M})$ were incubated for $60 \mathrm{~min}$ at room temperature in the equilibration buffer containing $500 \mu \mathrm{g} / \mathrm{ml} \mathrm{BSA}$, used as a carrier protein. To determine whether complex formation between test proteins was zinc dependent, control experiments were performed in an identical manner, but with $\mathrm{ZnCl}_{2}$ omitted from the equilibration buffer. To confirm that complex formation was not due to the association of ${ }^{125} \mathrm{I}-\mathrm{HKa}$ with BSA, control experiments were 
performed in which prourokinase $(550 \mu \mathrm{g} / \mathrm{ml})$ was substituted for BSA as a carrier protein. After the 1-h incubation, chromatography was performed at room temperature with a stable upward flow rate of $4 \mathrm{ml} / \mathrm{h}$, maintained using a P-1 peristaltic pump (Pharmacia). $0.5-\mathrm{ml}$ fractions were collected in an LKB 2112 Redirack fraction collector and analyzed for radioactivity after their collection.

The elution volume of ${ }^{125}$ I-labeled HKa or HK is expressed as the Kav, which represents the fraction of the stationary gel volume available for diffusion of a given solute species. As defined by Ackers (43), $K a v=V e-V o / V t-V o$, where $\mathrm{Ve}$ is the elution volume of the sample, $\mathrm{Vt}$ is the total volume of the packed bed, and Vo is the void volume of the column, determined by measuring the elution volume of ${ }^{125} \mathrm{I}$-labeled fibrinogen in independent experiments. The significance of differences in the Kav for ${ }^{125} \mathrm{I}-\mathrm{HKa}$ or ${ }^{125} \mathrm{I}$-HK under differing experimental conditions was determined using the Student's $t$ test for paired samples.

\section{Results}

Evaluation of the endothelial cell vitronectin/fibrinogen receptor $\left(\alpha_{v} \beta_{3}\right)$ as an HKa binding site. Under our experimental conditions, the binding of HKa was linear over a concentration range of 10-80 $\mathrm{nM}$, with nonspecific binding (determined in the absence of $\mathrm{ZnCl}_{2}$ ) constituting $<20 \%$ of total binding. Therefore, we selected an HKa concentration of $70 \mathrm{nM}$ to use in competitive binding studies in order to detect concentration-dependent inhibition of binding. Since HK had been shown previously to bind to $\alpha_{M} \beta_{2}$ (Mac-1), a neutrophil integrin receptor which binds fibrinogen (5), we initially postulated that a related receptor on endothelial cells, $\alpha_{v} \beta_{3}$ (44), might also function as a receptor for HKa. To address this hypothesis, we assessed the ability of vitronectin to compete with ${ }^{125} \mathrm{I}-\mathrm{HKa}$ for binding to HUVEC. We observed that over a concentration range of $20-175 \mathrm{nM}$, vitronectin competitively inhibited the binding of $70 \mathrm{nM}^{125} \mathrm{I}-\mathrm{HKa}$ (Fig. 1), with complete inhibition obtained at a concentration of $150 \mathrm{nM}$. These results were consistent with inhibition of binding of ${ }^{125} \mathrm{I}-\mathrm{HKa}$ to $\alpha_{\mathrm{v}} \beta_{3}$ by vitronectin. To further investigate this hypothesis, we determined whether fibrinogen, another $\alpha_{v} \beta_{3}$ ligand, also inhibited

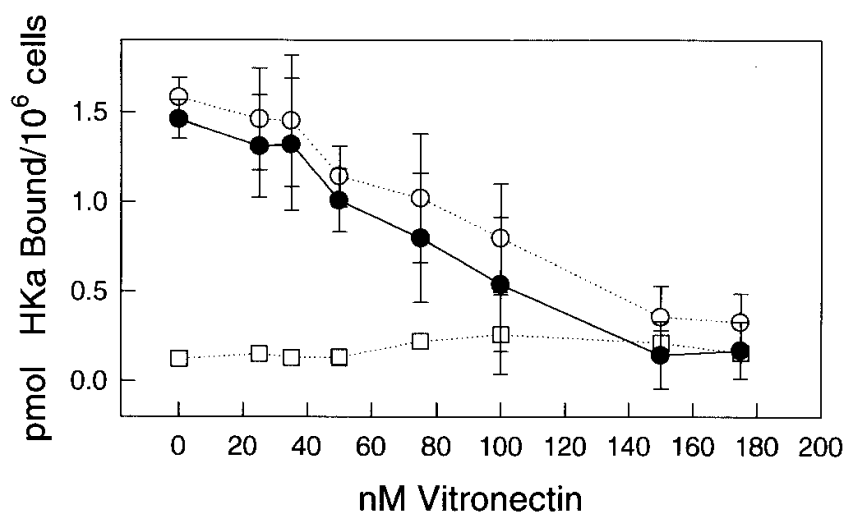

Figure 1. ${ }^{125} \mathrm{I}-\mathrm{HK}$ binding to HUVEC in the presence of increasing concentrations of vitronectin. Mixtures of ${ }^{125} \mathrm{I}-\mathrm{HKa}(70 \mathrm{nM})$ and various concentrations of vitronectin $(0-175 \mathrm{nM})$ were incubated with HUVEC for $60 \mathrm{~min}$ at $4^{\circ} \mathrm{C}$ and binding was measured as described in Methods. Total (open circles), nonspecific (open squares), and specific (filled circles) binding are depicted. Each data point represents the mean $\pm \mathrm{SD}$ of triplicate determinations. This figure is representative of three experiments performed.
Table I. Effect of Fibrinogen, $m A b$ 7E3, and Prourokinase on Binding of ${ }^{125} \mathrm{I}-\mathrm{HKa}$ to HUVEC

\begin{tabular}{|c|c|c|c|c|c|c|}
\hline \multicolumn{2}{|c|}{ Fibrinogen } & \multicolumn{3}{|c|}{$\begin{array}{l}\text { mAb 7E3 }(\mathrm{A}) \text { and } \\
\text { control mouse IgG }(\mathrm{B})\end{array}$} & \multicolumn{2}{|c|}{ Prourokinase } \\
\hline $\begin{array}{l}\text { Conc } \\
(\mathrm{nM})\end{array}$ & $\%$ control & $\begin{array}{l}\text { Conc } \\
(\mathrm{nM})\end{array}$ & $\begin{array}{l}\% \text { control } \\
\text { (A) }\end{array}$ & $\begin{array}{l}\% \text { control } \\
\text { (B) }\end{array}$ & $\begin{array}{l}\text { Conc } \\
(\mathrm{nM})\end{array}$ & $\%$ control \\
\hline 0 & $100 \pm 17$ & 0 & $100 \pm 19$ & $100 \pm 25$ & 0 & $100 \pm 20$ \\
\hline 140 & $84 \pm 15$ & 133 & $106 \pm 17$ & $104 \pm 27$ & 50 & $136 \pm 13$ \\
\hline 420 & $90 \pm 16$ & 533 & $101 \pm 21$ & $107 \pm 25$ & 100 & $104 \pm 14$ \\
\hline 560 & $91 \pm 9$ & 933 & $98 \pm 21$ & $117 \pm 35$ & 200 & $119 \pm 6$ \\
\hline 910 & $88 \pm 6$ & 1333 & $116 \pm 25$ & $91 \pm 25$ & 300 & $123 \pm 11$ \\
\hline 1400 & $96 \pm 11$ & 1600 & $119 \pm 20$ & $85 \pm 24$ & 500 & $88 \pm 9$ \\
\hline 3500 & $107 \pm 30$ & 2000 & $60 \pm 10$ & $97 \pm 12$ & & \\
\hline
\end{tabular}

Data represent the mean \pm SEM of triplicate points of at least two experiments, and are depicted as the percent binding relative to that in the absence of the test protein. Conc, concentration.

the binding of HKa to HUVEC. Despite the fact that ${ }^{125}$ I-fibrinogen bound to endothelial cells saturably over a range of 50$400 \mathrm{nM}$ (not shown), unlabeled fibrinogen did not inhibit the binding of $70 \mathrm{nM}^{125} \mathrm{I}-\mathrm{HK}$ a to HUVEC, even at concentrations up to $3,500 \mathrm{nM}$, a 50 -fold molar excess relative to the concentration of ${ }^{125} \mathrm{I}-\mathrm{HKa}$ (Table I).

Since these results did not support the hypothesis that ${ }^{125} \mathrm{I}$ HKa bound to $\alpha_{v} \beta_{3}$, we further investigated the potential interactions of $\mathrm{HKa}$ with this receptor by determining whether $\mathrm{mAb} 7 \mathrm{E} 3$, which is directed to the $\beta_{3}$ integrin chain and inhibits the binding of fibrinogen and vitronectin to $\alpha_{\mathrm{v}} \beta_{3}$, inhibited the binding of ${ }^{125} \mathrm{I}-\mathrm{HK}$ a to HUVEC. We observed that $7 \mathrm{E} 3 \mathrm{did}$ not significantly inhibit the binding of ${ }^{125} \mathrm{I}-\mathrm{HKa}$ to HUVEC, even at concentrations up to 2,000 nM (a 29-fold molar excess) (Table I). Thus, the results of these latter experiments suggested that the observed inhibition of ${ }^{125} \mathrm{I}-\mathrm{HK}$ binding to HUVEC was mediated through interactions with a receptor distinct from $\alpha_{\mathrm{v}} \beta_{3}$.

Binding of HKa to the endothelial cell urokinase receptor. Previous studies have demonstrated that in addition to $\alpha_{v} \beta_{3}$, vitronectin binds to the urokinase receptor at a site contained within domains 2 and/or 3 of $\operatorname{uPAR}(35,36)$. This site is functionally distinct from uPAR domain 1 , which binds pro- and two-chain urokinase $(32,33)$. Since $\mathrm{uPAR}$ are expressed by HUVEC (45-47), we hypothesized that the observed inhibition of HKa binding to these cells might involve interactions with this alternative vitronectin binding site. To address this issue, we first determined whether prourokinase affected the binding of ${ }^{125} \mathrm{I}-\mathrm{HKa}$ to endothelial cells. Consistent with our hypothesis that HKa did not interact with domain 1 of uPAR, we observed no inhibition of its binding to endothelial cells by prourokinase, even at prourokinase concentrations of up to $500 \mathrm{nM}$ (Table I). Next, we determined whether the binding of ${ }^{125} \mathrm{I}-\mathrm{HK}$ a to HUVEC was inhibited by affinity-purified polyclonal antibodies raised against domains 2 and 3 of uPAR. These antibodies blocked the binding of $70 \mathrm{nM}{ }^{125} \mathrm{I}-\mathrm{HKa}$ to HUVEC in a concentration-dependent manner $\left(\mathrm{IC}_{50}=180\right.$ $\mathrm{nM}$ ), with essentially complete inhibition achieved at an antibody concentration of $700 \mathrm{nM}(\sim 100 \mu \mathrm{g} / \mathrm{ml})$ (Fig. 2). No inhibition of ${ }^{125} \mathrm{I}-\mathrm{HKa}$ binding to HUVEC was caused by similar concentrations of nonimmune rabbit IgG. These observations 


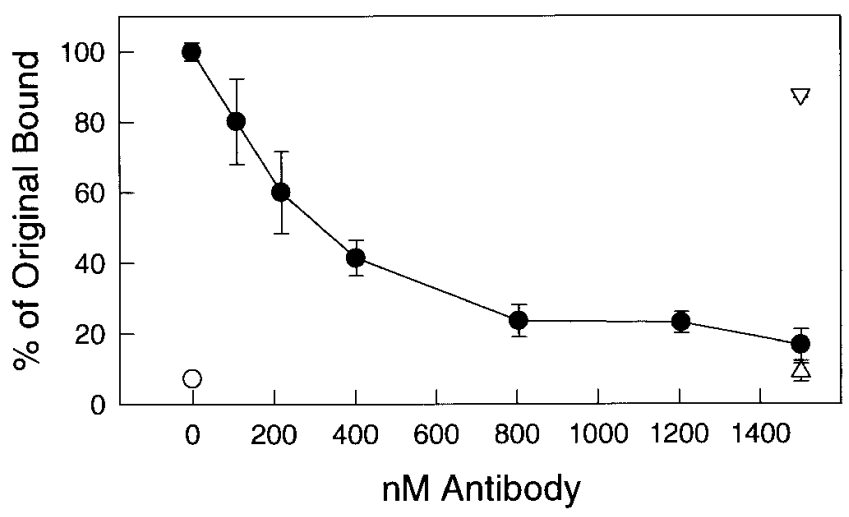

Figure 2. ${ }^{125} \mathrm{I}-\mathrm{HK}$ binding to HUVEC in the presence of increasing concentrations of rabbit polyclonal antibody specific to domains 2 and 3 of uPAR. HUVEC were incubated with various concentrations of anti-D2+D3 antibody $(0-1,500 \mathrm{nM})$ or control rabbit IgG for 30 min at $4^{\circ} \mathrm{C}$ before the addition of $70 \mathrm{nM}{ }^{125} \mathrm{I}-\mathrm{HKa}$. Incubation was continued for an additional $60 \mathrm{~min}$, and binding measured as described in Methods. Total binding in the presence of $50 \mu \mathrm{M} \mathrm{ZnCl}_{2}$ (filled circles); nonspecific binding in the absence of $\mathrm{ZnCl}_{2}$ (open circle); total binding in the presence of control antibody and $50 \mu \mathrm{M}$ $\mathrm{ZnCl}_{2}$ (triangle pointing down); nonspecific binding in the presence of control antibody, in the absence of $\mathrm{ZnCl}_{2}$ (triangle pointing up). The data represent the mean \pm SD of triplicate points from a single experiment representative of two performed.

suggested that HKa bound to a site within domains 2 and 3 of uPAR which was identical or closely apposed to the site which mediates the binding of vitronectin $(35,36)$.

To further address this possibility, we determined whether suPAR, containing amino acids 1-281 of the native receptor (truncated 2 amino acids $\mathrm{NH}_{2}$-terminal to the GPI linkage site), inhibited the binding of ${ }^{125} \mathrm{I}-\mathrm{HKa}$ to HUVEC. We observed that preincubation of $70 \mathrm{nM}{ }^{125} \mathrm{I}-\mathrm{HKa}$ with suPAR, in the presence of $50 \mu \mathrm{M} \mathrm{ZnCl}$, reduced its subsequent binding to HUVEC by $85 \%$ (Fig. 3). The $\mathrm{IC}_{50}$ for this interaction was $80 \mathrm{nM}$. These observations further support the hypothesis that

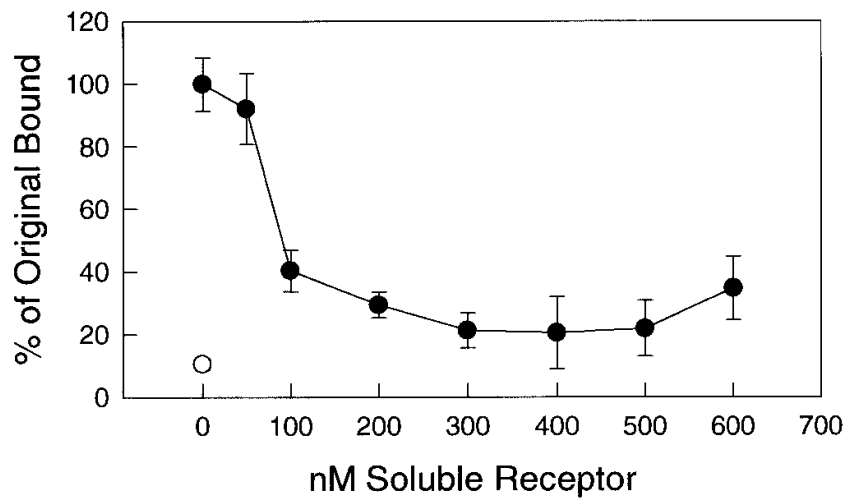

Figure 3. ${ }^{125} \mathrm{I}-\mathrm{HK}$ a binding to HUVEC in the presence of increasing concentrations of suPAR. Mixtures of ${ }^{125} \mathrm{I}-\mathrm{HKa}(70 \mathrm{nM})$ and various concentrations of suPAR $(0-600 \mathrm{nM})$ were preincubated at room temperature for $60 \mathrm{~min}$, then chilled to $4^{\circ} \mathrm{C}$. The mixtures were then added to HUVEC and incubated for $60 \mathrm{~min}$ at $4^{\circ} \mathrm{C}$. Binding was measured as described in Methods. Total binding in the presence of $50 \mu \mathrm{M}$ $\mathrm{ZnCl}_{2}$ (filled circles); nonspecific binding in the absence of $\mathrm{ZnCl}_{2}$ (open circle).
HKa interacts directly with UPAR, probably with 1:1 stoichiometry.

Effect of preincubation of endothelial cells with PI-PLC on binding of ${ }^{125} \mathrm{I}-\mathrm{HKa}$. The urokinase receptor is a GPI-linked protein, and previous studies have demonstrated that this receptor can be released from cell surfaces by treatment with PIPLC (31). Therefore, to further assess the role of uPAR in binding of ${ }^{125} \mathrm{I}-\mathrm{HKa}$, we measured binding after preincubation of HUVEC with PI-PLC. The specific binding of ${ }^{125}$ I-prourokinase was measured in parallel to determine the efficiency of uPAR release.

Pretreatment of HUVEC with PI-PLC caused an $87 \%$ reduction in the specific binding of ${ }^{125}$ I-prourokinase, as expected. A parallel reduction was observed in the specific binding of ${ }^{125} \mathrm{I}-\mathrm{HK}$ a to the treated cells, although its magnitude was slightly less than that observed for ${ }^{125}$ I-prourokinase binding (Fig. 4).

Demonstration of complex formation between $H K a$ and uPAR domains 2 and 3. To this point, our studies suggested that HKa bound directly to a site within domains 2 and 3 of endothelial cell UPAR. To further confirm this hypothesis, we determined whether HKa and suPAR interacted directly in a cell-free system. Gel-sieving chromatography, a method previously used to demonstrate the complexation of HK with kallikrein (1478), was used to illustrate the formation of complexes between HKa and suPAR. Incubation of $65 \mathrm{nM}{ }^{125} \mathrm{I}-$ HKa $\left(M_{\mathrm{r}} \sim 120,000\right)$ with $1 \mu \mathrm{M}$ suPAR $\left(M_{\mathrm{r}} \sim 55,000\right)$, in the presence of $50 \mu \mathrm{M} \mathrm{ZnCl}_{2}$, led to the formation of a high molecular weight complex which eluted near the void volume of the column (Table II). The Kav for this complex was $0.167 \pm 0.008$, and was significantly different from that of $\mathrm{HKa}$ alone, whether measured in the absence $(0.218 \pm 0.013)$ or presence $(0.232 \pm 0.006)$ of $\mathrm{ZnCl}_{2}$. The zinc dependence of this complex was confirmed by the observation that the formation of a high molecular weight complex between ${ }^{125} \mathrm{I}-\mathrm{HKa}$ and suPAR did not occur in the absence of $\mathrm{ZnCl}_{2}$ (Kav 0.218 \pm 0.013$)$. Furthermore, formation of the complex was not due to nonspecific as-

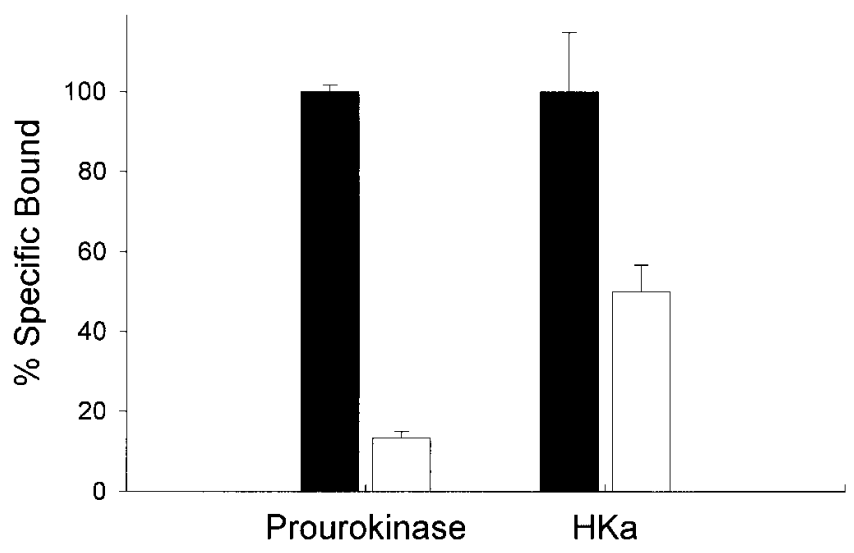

Figure 4. Effect of PI-PLC treatment on the binding of ${ }^{125} \mathrm{I}-\mathrm{HKa}$ and ${ }^{125}$ I-proUK to HUVEC. Cells were preincubated with $1 \mathrm{U} / \mathrm{ml}$ of PIPLC as described in Methods. The total and nonspecific binding of each of the radiolabeled ligands to control and PI-PLC-treated cells was then determined, and the specific binding, displayed in the figure, was calculated. These data represent the mean \pm SEM of quadruplicate points from a single experiment representative of three performed. 
Table II. Analysis of HK(a)-uPAR Complex Formation by Gel Filtration

\begin{tabular}{rlccc}
\hline \multicolumn{1}{c}{ Condition } & $\mathrm{Kav}^{*}$ & $n$ & $P^{\ddagger}$ \\
\hline $1 \mathrm{HKa}+\mathrm{Zn}^{2+}$ & $0.232 \pm 0.006$ & 5 & \\
2 & $\mathrm{HKa}+\mathrm{Zn}^{2+}+\operatorname{suPAR}$ & $0.167 \pm 0.008$ & 6 & $<0.001$ (vs. 1) \\
3 & $\mathrm{HKa}-\mathrm{Zn}^{2+}$ & $0.218 \pm 0.013$ & 4 & \\
4 & $0.212 \pm 0.001$ & 3 & 0.695 (vs. 3) \\
& $\mathrm{HKa}-\mathrm{Zn}^{2+}-\operatorname{suPAR}$ & 0.223 & 1 & \\
$5 \mathrm{HKa}+\mathrm{Zn}^{2+}($ proUK) & & & 0.007 (vs. 2) \\
6 & $\mathrm{HKa}+\mathrm{Zn}^{2+}+$ suPAR (proUK) & 0.170 & 2 & 0.829 (vs. 2) \\
7 & $\mathrm{HK}+\mathrm{Zn}^{2+}$ & 0.266 & 1 & \\
8 & $\mathrm{HK}+\mathrm{Zn}^{2+}+$ suPAR & 0.271 & 2 & \\
9 & $\mathrm{HK}-\mathrm{Zn}^{2+}$ & 0.234 & 2 & \\
10 & $\mathrm{HK}-\mathrm{Zn}^{2+}+$ suPAR & $0.223 \pm 0.006$ & 3 & \\
& & & & \\
\end{tabular}

* Kav (defined in Methods) is depicted as the mean \pm SEM of $n$ experiments. ${ }^{\S}$ ProUK depicts experiments in which prourokinase $(550 \mu \mathrm{g} / \mathrm{ml})$ was substituted for BSA as a carrier protein. ${ }^{\ddagger} P$ values were derived using the Student's $t$ test for paired samples.

sociation of HKa with the BSA carrier protein, since complex formation was not observed in the absence of suPAR and $\mathrm{ZnCl}_{2}$, regardless of whether BSA or prourokinase was used as the carrier protein. Complex formation also did not occur when uncleaved ${ }^{125} \mathrm{I}-\mathrm{HK}$ was substituted for ${ }^{125} \mathrm{I}-\mathrm{HKa}$, further demonstrating the specificity of the interaction between suPAR and HKa (Table II). Finally, a high molecular weight complex with a Kav similar to that of the HKa-suPAR complex was observed after incubation of ${ }^{125} \mathrm{I}-\mathrm{HKa}$ with isolated UPAR domains 2 and 3, demonstrating that the structural information necessary for $\mathrm{HKa}$ binding is contained within this region of the receptor (Fig. 5).

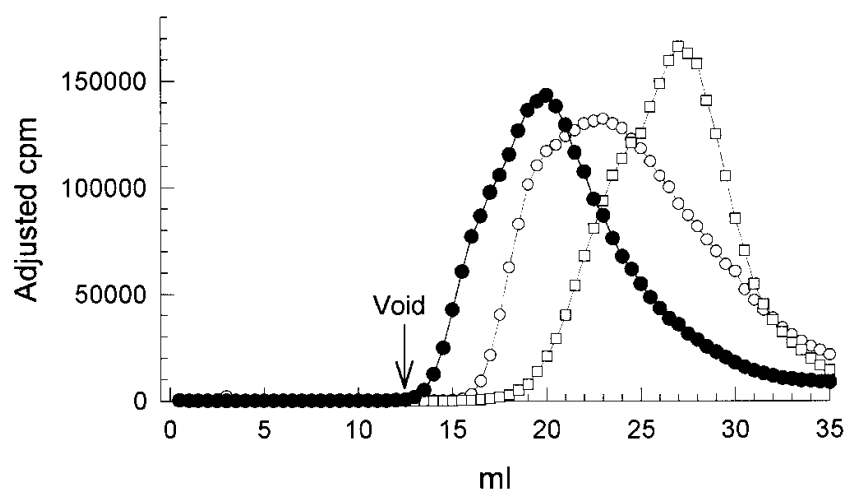

Figure 5. Gel filtration chromatography of $\mathrm{HKa}$ and suPAR domains 2 and 3. G-200 Sepharose Superfine was packed into a $0.9 \times 60 \mathrm{~cm}$ polystyrene column and equilibrated with a buffer containing $50 \mu \mathrm{M}$ $\mathrm{ZnCl}_{2}$ (see Methods). A stable flow rate of $4 \mathrm{ml} / \mathrm{h}$ was maintained in an upward direction using a P-1 peristaltic pump (Pharmacia). A $150-\mu \mathrm{l}$ volume of each sample was injected, and 0.5 -ml fractions were collected from the time of injection. Symbols are as follows: open squares, $340 \mathrm{nM}^{125} \mathrm{I}$-suPAR; open circles, $18 \mathrm{nM}{ }^{125} \mathrm{I}$-HKa; and filled circles, $18 \mathrm{nM}{ }^{125} \mathrm{I}-\mathrm{HKa}+7.2 \mu \mathrm{M}$ suPAR domains 2 and 3 . The void volume was determined using ${ }^{125}$ I-labeled fibrinogen.

\section{Discussion}

The binding of HK and HKa to endothelial cells has been appreciated for many years, although the cellular binding sites which mediate these interactions have not been identified. The studies described above suggest that at least one such binding site for the latter is the urokinase receptor. This conclusion is based on several observations. First, the binding of ${ }^{125} \mathrm{I}-\mathrm{HK}$ a to endothelial cells was inhibited by vitronectin, suggesting that $\mathrm{HKa}$ and vitronectin compete for the same binding site on the endothelial cell surface. One site to which both of these ligands might bind is the vitronectin receptor $\alpha_{v} \beta_{3}$. However, the binding of HKa to endothelial cells was not inhibited by either a known $\alpha_{v} \beta_{3}$ ligand, fibrinogen, or a specific anti- $\beta_{3}$ integrin monoclonal antibody known to inhibit vitronectin binding to $\alpha_{v} \beta_{3}$, suggesting that the vitronectin receptor does not mediate the binding of $\mathrm{HKa}$ to endothelial cells. In contrast, the binding of ${ }^{125} \mathrm{I}-\mathrm{HK}$ a to endothelial cells was inhibited by both polyclonal antibodies raised against domains 2 and 3 of the urokinase receptor, as well as the recombinant, soluble receptor itself. Furthermore, the binding of HKa to HUVEC was reduced after pretreatment of cells with PI-PLC, which releases the GPI-linked uPAR from the cell surface. These observations suggest a direct interaction of $\mathrm{HKa}$ with a binding site within domains 2 and 3 of UPAR, which is likely identical to that previously shown to mediate the binding of vitronectin $(35,36)$. This hypothesis is strengthened by the demonstration of a zinc-dependent interaction between ${ }^{125} \mathrm{I}-\mathrm{HKa}$ and both suPAR and UPAR domains 2 and 3 in a cell-free system, as evidenced by an increase in molecular size (decreased Kav) on gel filtration (Table II). Of interest is the fact that we were unable to demonstrate the formation of a complex between ${ }^{125} \mathrm{I}$ labeled HK and suPAR. This observation suggests that uncleaved HK does not bind to UPAR, or does so less avidly than $\mathrm{HKa}$, with the lower affinity complex dissociating during gel filtration. Consistent with the results of previous studies that demonstrated, using circular dichroism (48) and electron microscopy (49), that HK undergoes extensive conformational change upon its activation to $\mathrm{HKa}$, it is notable that the apparent molecular size of $\mathrm{HK}$, as assessed by gel filtration, differed from that of HKa (Table II). Such considerations make it plausible that the primary endothelial receptor for HK may be a protein other than uPAR. After the activation of cell bound $\mathrm{HK}$ to $\mathrm{HKa}$, the latter might then bind with greater affinity to the urokinase receptor.

Recently, Herwald et al. (50) isolated a protein from EAHY cells, identified as the $\mathrm{gClq}$ receptor, which bound to immobilized HK (51). Joseph et al. (52) have also demonstrated that this protein serves as a binding site for $\mathrm{HK}$ on HUVEC. The latter, but not the former, group reported that the binding of $\mathrm{HK}$ to the gC1q-R was zinc dependent (52), and also that the binding of ${ }^{125} \mathrm{I}$-labeled HK to HUVEC could be inhibited by selected antibodies raised against this protein, although $\mathrm{C} 1 \mathrm{q}$ itself did not compete for binding. The relationship between this binding site and UPAR is uncertain. HK appears to have different receptors on different cell types; for example, it binds in a zinc-dependent manner to Mac-1 (CD11b/CD18) on neutrophils (53) and glycoprotein Ib on unactivated platelets (54). On activated platelets, HK binds to cell-associated thrombospondin, released from $\alpha$-granules after platelet activation, although zinc dependence of this interaction has not been demonstrated (55). 
The inability of pretreatment of HUVEC with PI-PLC to reduce the binding of $\mathrm{HKa}$ to the same extent as prourokinase suggests that an additional endothelial binding site for $\mathrm{HKa}$, in addition to UPAR, may exist. However, the essentially complete inhibition of specific $\mathrm{HKa}$ binding by antibodies directed against UPAR domains 2 and 3 or soluble recombinant uPAR suggests that such a site might, under normal conditions, either exist in a complex, or at least in close spatial proximity to UPAR, and therefore be sterically hindered by reagents which bind to uPAR domains 2 and 3. Such a site might thus appear more prominent after PI-PLC treatment of cells. A precedent for such an association is the Mac-1-uPAR complex on monocytes (56), and direct associations of UPAR with other cellular integrins have also been demonstrated (57). Regardless, our studies expand knowledge concerning cellular kininogen binding sites by suggesting that different species of $\mathrm{HK}$, specifically the uncleaved and cleaved forms, might bind to different primary sites on the same cell.

The potential physiological implications of interactions between HKa and uPAR are numerous. One implication concerns the capacity of the contact activation system to facilitate the expression of cell surface plasminogen activator activity. A major role of UPAR is to focus the expression of cell surface plasminogen activator activity to discrete areas on the cell surface $(25,29,58)$. Ellis et al. have shown that the u-PAmediated activation of plasminogen is greatly facilitated in the presence of uPAR-expressing U937 cells, the effect of which is primarily to increase the catalytic efficiency $\left(k_{\text {cat }} / K_{\mathrm{m}}\right)$ of the reciprocal reaction involving plasmin-mediated activation of prourokinase (59). However, receptor-bound prourokinase may also be directly activated by kallikrein, which binds with high affinity to endothelial cells via interactions with cellbound $\mathrm{HK}$ or $\mathrm{HKa}$. We have shown recently that preincubation of HUVEC with HK and kallikrein enhances the ability of these cells to promote the generation of cell surface plasmin, and that this enhancement may be blocked by peptides which inhibit the binding of kallikrein to cell-bound $\mathrm{HK}(\mathrm{a})$ (60). Based on these results, as well as the studies presented in this report, we hypothesize that promotion of cell surface plasminogen activator activity by $\mathrm{HK}$ and kallikrein results from the formation of a multiprotein complex which includes these two proteins, as well as UPAR and proUK. The formation of this complex may be initiated by binding of HKa, perhaps generated from cell-bound HK by the actions of either an endothelial-derived cysteine protease (8), or Factor XIIa (61), to uPAR domains 2 and 3. HKa may then function as an acquired receptor for kallikrein, which, as a consequence of its favorable spatial localization relative to UPAR domain 1, may directly activate $\mathrm{UPAR}$-bound prourokinase.

Yet another process which may be influenced by the binding of HK to UPAR is that of cell adhesion. In addition to its role in facilitating the expression of cell surface plasminogen activator activity, the urokinase receptor may promote cellular adhesion by mediating the binding of cells to vitronectin (35, 36). Asakura et al. (37) have demonstrated the ability of $\mathrm{HKa}$, but not uncleaved $\mathrm{HK}$, to inhibit the adhesion and spreading of endothelial, osteosarcoma or melanoma cells on vitronectin, as well as other substrates. However, the mechanisms accountable for these effects were not defined, and we propose that the ability of $\mathrm{HKa}$ to compete for vitronectin binding sites on uPAR domains 2 and 3 may be involved in inhibition of cellular adhesion to vitronectin. This hypothesis, if confirmed, would suggest that through its ability to promote kallikreinmediated prourokinase activation and inhibit cellular adhesion to matrix-associated vitronectin, HK may play a prominent role in processes involving cellular migration and/or invasion, such as angiogenesis, tumor metastasis, placentation, and the migration of leukocytes into inflammatory foci. Our model also suggests that the antiadhesive effects of HKa and plasminogen activator inhibitor type 1 (PAI-1), which has been shown recently to inhibit uPAR-dependent cellular adhesion by competing with $\mathrm{uPAR}$ for binding to the same region of the vitronectin somatomedin B domain (62), may be mediated through a similar pathway.

\section{Acknowledgments}

We thank the nursing staff of the delivery ward at Temple University Hospital for their assistance in collecting umbilical cords for isolation of the endothelial cells used in these studies, and Su-May Lee for her technical assistance.

This work was supported by National Institutes of Health grant HL-50827 and a grant-in-aid (95-1022) from the National American Heart Association (both to K.R. McCrae), by National Institutes of Health grant P01-HL56914 (to R.W. Colman), and by a grant-in-aid from the American Heart Association Southeastern Pennsylvania Affiliate (to R.A. Pixley).

\section{References}

1. Schmaier, A.H., A. Kuo, D. Lundberg, S. Murray, and D.B. Cines. 1988. The expression of high molecular weight kininogen on human umbilical vein endothelial cells. J. Biol. Chem. 263:16327-16333.

2. van Iwaarden, F., P.G. deGroot, and B.N. Bouma. 1988. The binding of high molecular weight kininogen to cultured human umbilical vein endothelial cells. J. Biol. Chem. 263:4698-4703.

3. Hasan, A.A.K., D.B. Cines, J.R. Ngaiza, E.A. Jaffe, and A.H. Schmaier. 1995. High-molecular weight kininogen is exclusively membrane bound on endothelial cells to influence activation of vascular endothelium. Blood. 85:31343143 .

4. van Iwaarden, F., P.G. deGroot, J.J. Sixma, M. Berrettini, and B.N. Bouma. 1988. High molecular weight kininogen is present in cultured human endothelial cells; localization, isolation and characterization. Blood. 71:12681276.

5. Berrettini, M., R.R. Schleef, M.J. Heeb, P. Hopmeier, and J.H. Griffin. 1992. Assembly and expression of an intrinsic factor IX activator complex on the surface of cultured human endothelial cells. J. Biol. Chem. 267:1983319839.

6. Tait, J.F., and K. Fujikawa. 1987. Primary structure requirements for the binding of human high molecular weight kininogen to plasma prekallikrein and factor XI. J. Biol. Chem. 262:11651-11656.

7. Tait, J.F., and K. Fujikawa. 1986. Identification of the binding site for plasma prekallikrein in human high molecular weight kininogen. A region from residues 185 to 224 of the kininogen light chain retains full binding activity. $J$. Biol. Chem. 261:15396-15401.

8. Motta, G., A.A.K. Hasan, D.B. Cines, and A.H. Schmaier. 1995. High molecular weight kininogen and prekallikrein assembly on endothelial cells and produce plasminogen activation independent of Factor XII. Blood. 86(Suppl.): $374 \mathrm{a}$.

9. Nishikawa, K., Y. Shibayama, P. Kuna, E. Calcaterra, A.P. Kaplan, and S.R. Reddigari. 1992. Generation of vasoactive peptide bradykinin from human umbilical vein endothelium-bound high molecular weight kininogen by plasma kallikrein. Blood. 80:1980-1988.

10. McEachern, A.E., E.R. Shelton, R. Bhakta, R. Obernolte, C. Bach, P. Zuppan, J. Fujisaki, R.W. Aldrich, and K. Jarnagin. 1991. Expression cloning of a rat B2 bradykinin receptor. Proc. Natl. Acad. Sci. USA. 88:7724-7728.

11. Nakashima, M., J.V. Mombouli, A.A. Taylor, and P.M. Vanhoutte. 1993. Endothelium-dependent hyperpolarization caused by bradykinin in human coronary arteries. J. Clin. Invest. 92:2867-2871.

12. Hong, S.L. 1980. Effect of bradykinin and thrombin on prostacyclin synthesis in endothelial cells from calf and pig aorta and human umbilical cord vein. Thromb. Res. 18:787-795.

13. Holland, J.A., K.A. Pritchard, M.A. Pappolla, M.S. Wolin, N.J. Rogers, and M.B. Stemerman. 1990. Bradykinin induces superoxide anion release from human endothelial cells. J. Cell. Physiol. 143:21-25.

14. Smith, D., M. Gilbert, and W.G. Owen. 1985. Tissue plasminogen acti- 
vator release in vivo in response to vasoactive agents. Blood. 66:835-839.

15. Palmer, R.M.J., A.G. Ferrige, and S. Moncada. 1987. Nitric oxide release accounts for the biologic activity of endothelium derived relaxing factor. Nature (Lond.). 327:524-526.

16. Hasan, A.A.K., D.B. Cines, J. Zhang, and A.H. Schmaier. 1994. The carboxyl terminus of bradykinin and amino terminus of the light chain of kininogens comprise an endothelial cell binding domain. J. Biol. Chem. 269:3182231830 .

17. DeLa Cadena, R.A., Y.T. Wachtfogel, and R.W. Colman. 1994. Contact activation pathway: inflammation and coagulation. In Hemostasis and Thrombosis: Basic Principles and Clinical Practice. R.W. Colman, J. Hirsh, V.J. Marder, and E.W. Salzman, editors. Lippincott Co., Philadelphia. 223-234.

18. Reddigari, S.R., P. Kuna, G. Miragliotta, Y. Shibayama, K. Nishikawa, and A.P. Kaplan. 1993. Human high molecular weight kininogen binds to human umbilical vein endothelial cells via its heavy and light chains. Blood. 81: $1306-1311$

19. Jiang, Y.P., W. Muller-Esterl, and A.H. Schmaier. 1992. Domain 3 of kininogen contains a cell binding site and a site that modifies thrombin activation of platelets. J. Biol. Chem. 267:3712-3717.

20. Herwald, H., A.A.K. Hasan, J. Godovac-Zimmerman, A.H. Schmaier, and W. Muller-Esterl. 1995. Identification of an endothelial cell binding site on kininogen domain D3. J. Biol. Chem. 270:14634-14642.

21. Hasan, A.A.K., D.B. Cines, H. Herwald, A.H. Schmaier, and W. Muller-Esterl. 1995. Mapping the cell binding site on high molecular weight kininogen domain 5. J. Mol. Biol. 219:717-725.

22. DeLa Cadena, R.A., and R.W. Colman. 1992. The sequence HGLGHGEQQHGLGHGH in the light chain of high molecular weight kininogen serves as a primary structural feature for zinc-dependent binding to an anionic surface. Protein Sci. 1:151-160.

23. Kunapuli, S.P., R.A. DeLa Cadena, and R.W. Colman. 1993. Deletion mutagenesis of high molecular weight kininogen light chain: identification of two anionic surface binding subdomains. J. Biol. Chem. 268:2486-2492.

24. Ellis, V., N. Behrendt, and K. Dano. 1991. Plasminogen activation by receptor-bound urokinase. J. Biol. Chem. 266:12752-12758.

25. Ellis, V., C. Pyke, J. Eriksen, H. Solberg, and K. Dano. 1992. The urokinase receptor: involvement in cell surface proteolysis and cancer invasion. Ann. NY Acad. Sci. 667:13-31.

26. Bacharach, E., A. Itin, and E. Keshet. 1992. In vivo patterns of expression of urokinase and its inhibitor PAI-1 suggest a concerted role in regulating physiological angiogenesis. Proc. Natl. Acad. Sci. USA. 89:10686-10690.

27. Folkman, J., and Y. Shing. 1992. Angiogenesis. J. Biol. Chem. 267: 10931-10934.

28. Folkman, J. 1992. Angiogenesis in female reproductive organs. In Steroid Hormones and Uterine Bleeding. N.H. Alexander and C. d'Arcangus, editors. AAAS Press, Washington, DC. 143-158

29. Pollanen, J., R.W. Stephens, and A. Vaheri. 1991. Directed plasminogen activation at the surface of normal and malignant cells. Adv. Cancer Res. 57: 273-328

30. Ploug, M., N. Behrendt, D. Lober, and K. Dano. 1991. Protein structure and membrane anchorage of the cellular receptor for urokinase type plasminogen activator. Semin. Thromb. Hemost. 17:183-193.

31. Ploug, M., E. Ronne, N. Behrendt, A.L. Jensen, F. Blasi, and K. Dano. 1991. Cellular receptor for urokinase plasminogen activator; carboxyl-terminal processing and membrane anchoring by glycosyl-phosphatidylinositol. J. Biol. Chem. 266:1926-1933.

32. Behrendt, N., M. Ploug, L. Patthy, G. Houen, F. Blasi, and K. Dano. 1991. The ligand-binding domain of the cell surface receptor for urokinase-type plasminogen activator. J. Biol. Chem. 266:7842-7847.

33. Pollanen, J. 1993. The N-terminal domain of human urokinase receptor contains two distinct regions critical for ligand recognition. Blood. 82:2719-2729.

34. Ploug, M., V. Ellis, and K. Dano. 1994. Ligand interaction between urokinase-type plasminogen activator and its receptor probed with 8-anilino1-napthalenesulfonate. Evidence for a hydrophobic binding site exposed only on the intact receptor. Biochemistry. 33:8991-8997.

35. Wei, Y., D.A. Waltz, N. Rao, R.J. Drummond, S. Rosenberg, and H.A. Chapman. 1994. Identification of the urokinase receptor as an adhesion receptor for vitronectin. J. Biol. Chem. 269:32380-32388.

36. Waltz, D.A., and H.A. Chapman. 1994. Reversible cellular adhesion to vitronectin linked to urokinase receptor occupancy. J. Biol. Chem. 269:1474614750 .

37. Asakura, S., R.W. Hurley, K. Skorstengaard, I. Ohkubo, and D.F. Mosher. 1992. Inhibition of cell adhesion by high molecular weight kininogen. J. Cell Biol. 116:465-476.

38. Fraker, P.J., and J.C. Speck, Jr. 1978. Protein and cell membrane iodinations with a sparingly soluble chloramide, 1,3,4,6-tetrochloro-3a,6a-diphenylglycoluril. Biochem. Biophys. Res. Commun. 80:849-857.

39. Jaffe, E.A., R.L. Nachman, C.G. Becker, and C.R. Minick. 1973. Culture of human endothelial cells derived from umbilical veins. J. Clin. Invest. 52:
2745-2753.

40. McCrae, K.R., A. DeMichele, P. Samuels, D. Roth, A. Kuo, Q. Meng, J. Rauch, and D.B. Cines. 1991. Detection of endothelial cell-reactive immunoglobulin in patients with anti-phospholipid antibodies. Br. J. Haematol. 79:595-605.

41. Maciag, T., J. Cerundolo, S. Ilsley, P.R. Kelley, and R. Forand. 1979. An endothelial cell growth factor from bovine hypothalamus: identification and partial characterization. Proc. Natl. Acad. Sci. USA. 76:5674-5678.

42. Zini, J.M., S.C. Murray, C.H. Graham, P.K. Lala, E.S. Barnathan, A Mazar, J. Henkin, D.B. Cines, and K.R. McCrae. 1992. Characterization of urokinase receptor expression by human placental trophoblasts. Blood. 79: 2917-2929.

43. Ackers, G.K. 1967. A new calibration procedure for gel filtration columns. J. Biol. Chem. 242:3237-3238.

44. Phillips, D.R., I.F. Charo, L.V. Parise, and L.A. Fitzgerald. 1988. The platelet membrane glycoprotein IIb-IIIa complex. Blood. 71:831-843.

45. Miles, L.A., E.G. Levin, J. Plescia, D. Collen, and E.F. Plow. 1988. Plasminogen receptors, urokinase receptors, and their modulation on human endothelial cells. Blood. 72:628-635.

46. Barnathan, E.S., A. Kuo, L. Rosenfeld, K. Kariko, M. Leski, F. Robbiati, M.L. Nolli, J. Henkin, and D.B. Cines. 1990. Interaction of single chain urokinase type plasminogen activator with human endothelial cells. J. Biol. Chem. 265:2865-2872.

47. Hajjar, K.A., and N.M. Hamel. 1990. Identification and characterization of human endothelial cell membrane binding sites for tissue plasminogen activator and urokinase. J. Biol. Chem. 265:2908-2916.

48. Villanueva, G.B., L. Leung, H. Bradford, and R.W. Colman. 1989. Conformation of high molecular weight kininogen: effects of kallikrein and factor XI cleavage. Biochem. Biophys. Res. Commun. 158:72-79.

49. Weisel, J.W., C. Nagaswami, J.L. Woodhead, R.A. DeLa Cadena, J.D. Page, and R.W. Colman. 1994. The shape of high molecular weight kininogen organization into structural domains, changes with activation and interactions with prekallikrein, as determined by electron microscopy. J. Biol. Chem. 269: 10100-10106.

50. Herwald, H., J. Dedio, R. Kellner, M. Loos, and W. Muller-Esterl. 1996. Isolation and characterization of the kininogen binding protein $\mathrm{p} 33$ from endothelial cells. J. Biol. Chem. 271:13040-13047.

51. Edgell, C.J.S., C.C. McDonald, and J.B. Graham. 1983. Permanent cell line expressing human factor VIII-related antigen established by hybridization. Proc. Natl. Acad. Sci. USA. 80:3734-3737.

52. Joseph, K., B. Ghebrehiwet, E.I.B. Peerschke, K.B.M. Reid, and A.P. Kaplan. 1996. Identification of the zinc-dependent endothelial cell binding protein for high molecular weight kininogen and factor XII: identity with the receptor that binds to the globular "heads" of C1q (gC1q-R). Proc. Natl. Acad. Sci. USA. 93:8552-8557.

53. Wachtfogel, Y.T., R.A. DeLa Cadena, S.P. Kannapuli, L. Rick, M. Miller, R.L. Schultze, D.C. Altieri, T.S. Edgington, and R.W. Colman. 1994 High molecular weight kininogen binds to Mac-1 on neutrophils by its heavy chain (domain 3) and its light chain (domain 5). J. Biol. Chem. 269:1930719312.

54. Bradford, H.N., R.A. DeLa Cadena, S.P. Kanapuli, J.F. Dong, J.A. Lopez, and R.W. Colman. 1996. Human kininogens regulate thrombin binding to platelets through the GPIb-IX complex. Blood. In press.

55. DeLa Cadena, R.A., E.G. Wyshock, S.P. Kanapuli, R.L. Schlutze, M. Miller, D.A. Waltz, and R.W. Colman. 1994. Platelet thrombospondin interactions with human high and low molecular weight kininogens. Thromb. Haemost. 72:125-131.

56. Simon, D.I., N.K. Rao, H. Xu, O. Majdic, E. Ronne, L. Kobjik, and H.A. Chapman. 1996. Mac-1 (CD11b/CD18) and the urokinase receptor (CD87) form a functional unit on monocytic cells. Blood. 88:3185-3194.

57. Wei, Y., M. Lukashev, D.I. Simon, S.C. Bodary, S. Rosenberg, M.V. Doyle, and H.A. Chapman. 1996. Regulation of integrin function by the urokinase receptor. Science (Wash. DC). 273:1551-1555.

58. Blasi, F. 1996. The urokinase receptor and cell migration. Semin. Thromb. Hemost. 22:513-516.

59. Ellis, V., M.F. Scully, and V.J. Kakkar. 1989. Plasminogen activation initiated by single-chain urokinase type plasminogen activator. J. Biol. Chem. 264: 2185-2188.

60. Lin, Y., R.B. Harris, W.Y. Yan, K.R. McCrae, and R.W. Colman. 1997. High molecular weight kininogen peptides inhibit the formation of kallikrein on endothelial surfaces and subsequent urokinase-dependent plasmin formation. Blood. 90:690-697.

61. Lenich, C., R. Pannell, and V. Gurewich. 1995. Assembly and activation of the intrinsic fibrinolytic pathway on the surface of human endothelial cells in culture. Thromb. Haemost. 74:698-703.

62. Deng, G., S.A. Curriden, S. Wang, S. Rosenberg, and D.J. Loskutoff. 1996. Is plasminogen activator inhibitor-1 the molecular switch that governs urokinase receptor-mediated cell adhesion and release? J. Cell Biol. 134:15631571. 